\title{
Analysis on Factors Causing Fatigue among Steel Casting Workers at PT X Sidoarjo
}

\author{
Analisis Faktor yang Berhubungan dengan Kelelahan pada Pekerja Bagian \\ Pengecoran Baja di PT X Sidoarjo
}

\author{
Muhammad Amin Jauhari \\ Technical Implementation Unit of Occupational Safety and Health \\ Department of Manpower and Transmigration, East Java Province \\ Jalan Dukuh Menanggal No. 122 Surabaya, East Java, Indonesia 60234
}

\begin{abstract}
Introduction: Fatigue is a common condition among workers as a protective mechanism to prevent their body from further damage. PT. X Sidoarjo is a company engaged in the manufacture of steel and wire rod. In the steel casting division, the workers experienced some fatigue. The steel casting workers experience a hot work climate since their work area was close to the billet burner furnace. The physical workload of the workers also affected the level of fatigue. Individual factors and sleep quality also affect the level of individual fatigue. The purpose of this research is to analyze the factors associated with fatigue among steel casting workers at PT. X Sidoarjo. Metods: This research is categorized as analytical observational research using the cross-sectional approach. The population of this study was 43 workers in the steel casting division at PT. X Sidoarjo. The sample of this research was 30 respondents based on simple random sampling method. The independent variables were individual factors, physical workload, work climate, and sleep quality; while the dependent variable was fatigue. Results: The results showed that there was a significant relationship between physical workload, work climate, and sleep quality with fatigue. There was no significant relationship between individual factors and fatigue. Conclusion: This research concluded that excessive workload, work climate, and poor sleep quality can cause fatigue among steel casting workers at PT. X Sidoarjo.
\end{abstract}

Keywords: fatigue, personal factors, physical workload, sleep quality, work climate

\begin{abstract}
ABSTRAK
Pendahuluan: Kelelahan merupakan kondisi yang umum terjadi pada pekerja sebagai mekanisme proteksi agar tubuh tidak mengalami kerusakan yang lebih lanjut. PT. X Sidoarjo merupakan perusahaan yang bergerak dibidang pembuatan baja dan kawat baja. Pada bagian pengecoran baja tampak adanya pekerja yang memiliki tanda kelelahan. Pekerja bagian pengecoran baja memiliki iklim kerja yang panas dikarenakan pekerjaan yang dilakukan dekat dengan tungku burner billet. Beban kerja fisik pada pekerja juga mempengaruhi tingkat kelelahan. Faktor individu dan kualitas tidur juga mempengaruhi tingkat kelelahan individu. Tujuan dari penelitian ini adalah untuk menganalisis faktor yang berhubungan dengan kelelahan pada pekerja bagian pengecoran baja di PT. X Sidoarjo. Metode: Penelitian ini adalah penelitian observasional analitik dengan menggunakan pendekatan cross sectional. Populasi penelitian adalah seluruh pekerja yang bekerja pada bagian pengecoran baja di PT. X Sidoarjo yang berjumlah 43 orang. Sampel penelitian berjumlah 30 orang yang dipilih menggunakan simple random sampling. Variabel independen adalah faktor individu, beban kerja fisik, iklim kerja, dan kualitas tidur. Variabel dependen adalah kelelahan. Hasil: Penelitian menunjukkan terdapat hubungan yang bermakna antara beban kerja fisik, iklim kerja, dan kualitas tidur dengan kelelahan. Tidak terdapat hubungan yang bermakna antara faktor individu dengan kelelahan. Simpulan: Beban kerja fisik yang berlebihan, iklim kerja dan kualitas tidur buruk dapat menyebabkan kelelahan pada pekerja bagian pengecoran baja di PT. $X$ Sidoarjo.
\end{abstract}

Kata kunci: beban kerja fisik, faktor individu, iklim kerja, kelelahan, kualitas tidur

Corresponding Author:

Muhammad Amin Jauhari

Email: Jauhari564@gmail.com

(C2019 IJOSH All right reserved. Open access under CC BY NC-SA license doi: 10.20473/ijosh.v8i2.2019. 224-232 Received 09 July 2018, received in revised form February 07, 2019, Accepted August 02, 2019, Published: August 2019 


\section{INTRODUCTION}

Occupational safety and health are the efforts in providing protection and facilities at the workplace for the employees. In an effort to regulate this, the government of the (President of the Republic of Indonesia, 1970).

President of the Republic of Indonesia (1970) stated that the management has the obligation to carry out the examination of bodily health, mental condition, and physical abilities of the workers to be accepted and transferred in accordance with the characteristics of the work given to them. The company is obligated to always monitor its worker's health so that there will be no occupational accident or diseases.

Fatigue commonly happens to all workers. Every worker acquires different body abilities. Fatigue is a warning and a part of protection system so that human body will not be severely damaged. Therefore, when the body experiences fatigue, it is recommended to take a break immediately (Tarwaka, 2015).

Grandjean (1979) explained that there are two theories of muscle fatigue process, namely the chemical and nerve theories. Both theories have a different perspective about the process of fatigue. The chemical theory argues that muscle fatigue is caused by reduced energy reserves and accumulation of metabolic waste in the body. Meanwhile, according to the nerve theory, the chemical process in the body only provides stimuli to the brain that propagates through some nerves to be then responded by the emergence of fatigue.

Fatigue can increase the risk of accidents, because when the body is tired, the level of alert decreases. The slowing body response as the impact of fatigue is also dangerous for workers since it will inhibit them from making swift decisions when something happens (Safe Work Australia, 2013).

Maurits (2010) explained that there are several individual factors causing accidents, such as working period, age, and nutritional status. There are also environmental factors like noise, work climate, and lighting. Another factor is workload. According to Safe Work Australia (2013), occupational fatigue is caused by several factors, such as the physical workload, sleep quality, shift work, and work environment.

Work climate can affect occupational fatigue if it exceedes the established threshold value. Human body is adjusted to maintain the almost constant temperature (homoeothermic) carried out by the thermoregulatory system (Suma'mur, 2009). The constant temperature is a balance between heat produced by the body and surrounding environment. The factors that affect heat exchange are conduction, convection, radiation, and evaporation from the surroundings. The combination of work climate and heavy physical workload will easily cause a person to experience occupational fatigue. A person who has poor sleep quality will easily experience fatigue, because his/her body does not get adequate rest at night when it should be resting.

Meanwhile, PT. X Sidoarjo is a company engaged in the manufacture of steel and wire rod. The produced outputs are steel and wire rod. The raw material comes from the scrap added by iron ore. The processing of raw materials to be steel and wire rod is carried out through several processes.

The first process is scrap smelting that is done in Steel Melting Shop (SMS) area. In this process, the scrap is smelted using the Electrical Arc Furnace (EAF) under a temperature of $1600^{\circ} \mathrm{C}$. This process aims to separate the steel and the produced residual waste (slag). The addition of ore and other materials is in accordance with the customer request. The addition utilizes the Ladle Refining Furnace (LRF) with a temperature of $1600^{\circ} \mathrm{C}$. The customized steel liquid is then molded using the Continuous Casting Machine (CCM). The output of the process is steel with the length and thickness based on customer request, or is usually called the billet.

The second process is conducted in Rolling Mill area. The billets are then reheated using Billet Reheating Furnace (BRF) with a temperature of approximately $1600^{\circ} \mathrm{C}$. The heating is done to turn the billets into liquids in order to simplify molding process into wire rod. The molded wire rod is then cooled down and quality control is carried out to see if the rod has already met the customer request.

Within the Billet Reheating Furnace (BRF) area, not all works are done automatically. There are still the manual works carried out by the workers. The works include deburring, slag cleaning, descaler operating, and sluice guarding. Those works require work intensity and monotony. Deburring is the work which cuts the billet to be inserted into the Billet Reheating Furnace (BRF). The cutting is done 
on the roll table placed right in front of the billet heating furnace. The work is carried out by slightly bending and this lasts for eight working hours. The slag cleaning is done in a room right under the billet heating furnace. The work done is shoveling the slag into buckets as the temporary containers. After the buckets are full, they will be transported back to the top and put into the wagons to be taken to the slag dump.

The temperature in the Billet Reheating Furnace (BRF) work area is extremely high, especially in the area near furnace. In the area under the furnace, airflow is blocked since the work area is located below ground level and right under the burner billet furnace.

Due to the hot temperature and heavy physical workload, many workers sweat in high intensity. Moreover, the signs of fatigue also appear in the workers, such as drowsiness and exhaustion. Fatigue also causes a decrease in someone's reaction time.

An accident can happen if a tired person keeps being forced to work. The purpose of this research is to analyze the relationship between individual factors, physical workload, work climate, as well as sleep quality and fatigue on the steel casting workers at PT. X Sidoarjo.

\section{METHODS}

This research was an analytical and observational research which employed crosssectional approach. The research was conducted at PT. X Sidoarjo on May 2018.

The population of this research was the workers at steel casting division at PT. X Sidoarjo, consisting of 34 workers. Sample calculation method utilized the simple random sampling and final sample was 30 workers.

There are two variables in this research, namely dependent and independent variables. The independent variables of this research were individual factors, physical workload, work climate, and sleep quality, while the dependent variable was occupational fatigue.

The primary data was obtained by field observation, interview, and questionnaire filled by the workers. The questionnaire measured the worker's sleep quality and was adapted from the Pittsburgh Sleep Quality Index (PSQI). Meanwhile, the secondary data was obtained from the company profile and the production process. Data collection for physical workloads was obtained by measuring the worker's pulse rate with the palpation method for 15 seconds.
The pulse measurement was conducted twice, before and during the work. The calculation was done using the Cardiovascular Load (CVL) formula to gain the workload category in accordance with \%CVL. Fatigue was measured using the reaction timer. The measurement was conducted shortly after the workers finished their job.

The obtained data were then processed through several steps, editing, coding, entry data, sorting, and tabulating data. The data analysis was conducted using Spearman correlation test $(\alpha=0.05)$ for ordinal data scale and chi-square test for nominal data scale.

\section{RESULTS}

\section{Characteristics of Respondents}

Age

Age variable represents respondents' ages when they participated in this research. The frequency distribution of respondent's age is divided into three categories and presented in Table 1. From the results, it can be seen that most respondents are in the age range of 25-35 years.

Table 1. The Frequency Distribution of Respondent's Age at PT. X Sidoarjo in 2018

\begin{tabular}{ccc}
\hline Age (year) & Number (people) & Percentage (\%) \\
\hline$<25$ & 6 & 20 \\
$25-35$ & 13 & 43.3 \\
$>35$ & 11 & 36.7 \\
\hline Total & 30 & 100 \\
\hline
\end{tabular}

\section{Working Period}

Working period signifies time counted from the respondent's first year to be employed at PT. X Sidoarjo until the day this research was conducted. Table 2 is the frequency distribution related to the respondent's working period. Majority of respondents have worked for less than 5 years $(46.7 \%)$.

Table 2. The Frequency Distribution of Respondent's Working Period at PT. X Sidoarjo in 2018

\begin{tabular}{ccc}
\hline $\begin{array}{c}\text { Working } \\
\text { Period (year) }\end{array}$ & Number (people) & Percentage (\%) \\
\hline$<5$ & 14 & 46.7 \\
$5-10$ & 5 & 16.7
\end{tabular}




\begin{tabular}{ccc}
$>10$ & 11 & 36.7 \\
\hline Total & 30 & 100 \\
\hline Physical Workload &
\end{tabular}

Physical Workload

The physical workload was measured using the Cardiovascular Load (CVL). The Cardiovascular Load was calculated by measuring the respondent's resting, working, and maximum heart rates. The pulse rate measurement utilized palpation method for 15 seconds. The frequency distribution according to the physical workload owned by the respondents is tabulated in Table 3. The measurement results indicate that most respondents had a moderate workload (73.3\%).

Table 3. The Results of Physical Workload Measurement at PT. X Sidoarjo in 2018

\begin{tabular}{ccc}
\hline $\begin{array}{c}\text { Physical } \\
\text { Workload }\end{array}$ & Number & $\begin{array}{c}\text { Percentage } \\
(\boldsymbol{\%})\end{array}$ \\
\hline Light & 5 & 16.7 \\
Moderate & 22 & 73.3 \\
Quite Heavy & 3 & 10 \\
\hline Total & 30 & 100 \\
\hline
\end{tabular}

\section{Work Climate}

The work climate measurement was measured using WBGT indicators. The results of work climate measurement can be observed in Table 4.

Table 4. The Results of Work Climate Measurement at PT. X Sidoarjo in 2018

\begin{tabular}{lccccc}
\hline \multicolumn{1}{c}{$\begin{array}{c}\text { Work } \\
\text { Location }\end{array}$} & $\begin{array}{c}\mathbf{T}_{\mathbf{w b}} \\
\left({ }^{\circ} \mathbf{C}\right)\end{array}$ & $\begin{array}{c}\mathbf{T}_{\mathbf{d b}} \\
\left({ }^{\circ} \mathbf{C}\right)\end{array}$ & $\begin{array}{c}\mathbf{T}_{\mathbf{g}} \\
\left({ }^{\circ} \mathbf{C}\right)\end{array}$ & $\begin{array}{c}\text { WBGT } \\
\left({ }^{\circ} \mathbf{C}\right)\end{array}$ & $\begin{array}{c}\text { RH } \\
(\%)\end{array}$ \\
\hline $\begin{array}{l}\text { Point A } \\
\text { BRF }\end{array}$ & 34.5 & 35.9 & 39.8 & 33.4 & 53 \\
$\begin{array}{l}\text { Point B } \\
\text { BRF }\end{array}$ & 30.7 & 38.1 & 48.8 & 35.8 & 43 \\
$\begin{array}{l}\text { Point A } \\
\text { Descaler }\end{array}$ & 28.1 & 35.3 & 38.0 & 31.2 & 46 \\
$\begin{array}{l}\text { Point B } \\
\text { Descaler }\end{array}$ & 27.5 & 34.3 & 35.7 & 30 & 49 \\
\hline
\end{tabular}

Table 4 demonstrates the measurement results that are divided into five, including Wet Bulb Temperature $\left(\mathrm{T}_{\mathrm{wb}}\right)$, Dry Bulb Temperature $\left(\mathrm{T}_{\mathrm{db}}\right)$, Global Temperature $\left(\mathrm{T}_{\mathrm{g}}\right)$, Wet-Bulb Globe Temperature (WBGT), and Rapid Humidity $(\mathrm{RH})$. The determination of work climate utilized the Wet-Bulb Globe Temperature (WBGT). The highest work climate is at point B of the Billet Reheating Furnace (BRF) with the Wet-Bulb Globe Temperature (WBGT) reaching $35.8^{\circ} \mathrm{C}$. Point $\mathrm{B}$ of the Billet Reheating Furnace (BRF) is the work area located right in front of the billet burner furnace. Point $\mathrm{B}$ of the Billet Reheating Furnace (BRF) is where the billet cutting using oxygen is carried out manually by the workers.

\section{Sleep Quality}

Sleep quality was measured using Pittsburgh Sleep Quality Index (PSQI). Sleep quality was categorized into two: poor and good. The sleep quality was assessed based on several questions related to the respondent's subjective sleep quality, night sleep efficiency, sleep latency, sleep duration, night sleep disturbance, and disruption of activity during the day.

Table 5 presents the measurement result of the respondent's sleep quality. Table 5 shows that most respondents (56.7\%) had poor sleep quality. The poor sleep quality shows the respondents had the PSQI value of more than 5 .

Table 5. The Results of Sleep Quality Measurement at PT. X Sidoarjo in 2018

\begin{tabular}{ccc}
\hline Sleep Quality & Number & Percentage (\%) \\
\hline Poor & 17 & 56.7 \\
Good & 13 & 43.3 \\
\hline Total & 30 & 100 \\
\hline
\end{tabular}

\section{The Relationship between Age and Fatigue}

Table 6. The Relationship between Age and Fatigue on the Steel Casting Workers at PT. X Sidoarjo in 2018

\begin{tabular}{lcccccc}
\hline \multirow{3}{*}{ Age } & \multicolumn{3}{c}{ Occupational Fatigue } & \multicolumn{2}{c}{ Total } \\
\cline { 2 - 6 } & \multicolumn{2}{c}{ Normal } & \multicolumn{2}{c}{ Light } & \multicolumn{2}{c}{} \\
\cline { 2 - 6 } & $\mathbf{n}$ & $\boldsymbol{\%}$ & $\mathbf{n}$ & $\mathbf{\%}$ & $\mathbf{N}$ & $\boldsymbol{\%}$ \\
\hline$<25$ & 6 & 100 & 0 & 0 & 6 & 100 \\
$25-35$ & 8 & 61.5 & 5 & 38.5 & 13 & 100 \\
$>35$ & 7 & 63.6 & 4 & 36.4 & 11 & 100 \\
\hline
\end{tabular}

From Table 6, it can be seen that five respondents (38.5\%) in the age range of 25-35 years experience light fatigue. The result of the Spearman correlation test shows the p-value of $0.22(\alpha=0.05)$ which means that there is no relationship between age and fatigue among steel casting workers at PT. X Sidoarjo. 


\section{The Relationship between Working Period and Fatigue}

The relationship between the working period and fatigue was discovered using the Spearman correlation test. The statistical test can be seen in Table 7 .

Table 7. The Relationship between Working Period and Fatigue at PT. X Sidoarjo in 2018

\begin{tabular}{lcccccc}
\hline \multirow{2}{*}{$\begin{array}{l}\text { Working } \\
\text { Period }\end{array}$} & \multicolumn{3}{c}{ Occupational Fatigue } & \multicolumn{2}{c}{ Total } \\
\cline { 2 - 5 } & \multicolumn{2}{c}{ Normal } & \multicolumn{2}{c}{ Light } & \multicolumn{2}{c}{} \\
\cline { 2 - 6 } & $\mathbf{n}$ & $\boldsymbol{\%}$ & $\mathbf{n}$ & $\boldsymbol{\%}$ & $\mathbf{N}$ & $\%$ \\
\hline$<5$ & 12 & 85.7 & 2 & 14.3 & 14 & 100 \\
$5-10$ & 3 & 60 & 2 & 40 & 5 & 100 \\
$>10$ & 6 & 54.4 & 5 & 45.5 & 11 & 100 \\
\hline
\end{tabular}

The results of the statistical test on Table 7 depicts that five respondents $(45.5 \%)$ who experienced light fatigue have worked for more than 10 years. The result of the Spearman correlation test showed the p-value of 0.09 ( $\alpha=$ 0.05 ), indicating that there is no relationship between the working period and fatigue.

\section{The Relationship between Physical Workload and Fatigue}

The physical workload obtained by measuring the pulse rate to be then calculated with the Cardiovascular Load (CVL) formula was then classified into five, namely light, moderate, quite heavy, heavy, and very heavy. The relationship between physical workload and fatigue that can be seen in Table 8 .

Table 8. The Relationship between Physical Workload and Fatigue at PT. X Sidoarjo in 2018

\begin{tabular}{|c|c|c|c|c|c|c|}
\hline \multirow{3}{*}{ Workload } & \multicolumn{4}{|c|}{ Occupational Fatigue } & \multirow{2}{*}{\multicolumn{2}{|c|}{ Total }} \\
\hline & \multicolumn{2}{|c|}{ Normal } & \multicolumn{2}{|c|}{ Light } & & \\
\hline & $\mathbf{n}$ & $\%$ & $\mathrm{n}$ & $\%$ & $\mathbf{N}$ & $\%$ \\
\hline Light & 5 & 100 & 0 & 0 & 5 & 100 \\
\hline Moderate & 15 & 68.2 & 7 & 31.8 & 22 & 100 \\
\hline $\begin{array}{l}\text { Quite } \\
\text { Heavy }\end{array}$ & 1 & 33.3 & 2 & 66.7 & 3 & 100 \\
\hline
\end{tabular}

Table 8 demonstrated that from 22 respondents who recorded moderate physical workload, seven (31.8\%) among them experienced quite heavy occupational work and two workers (66.7\%) experienced light occupational fatigue. Based on the Spearman statistical test result, the relationship between physical workload and fatigue had the p-value of $0.045(\alpha=0.05)$, which means that there is a relationship between physical workload and fatigue. The correlation coefficient value was 0,369 , which means that the relationship is weak.

\section{The Relationship between Work Climate and Fatigue}

The measurement result of work climate was categorized into two, that is less than or equal to TVL $(\leq$ TVL) and more than TVL (> TVL). These categorizations were adjusted based on the Regulation of the Minister of Manpower and Transmigration (2011) about Threshold Value Limits of Physical and Chemical Factors in the Workplace. The crosstabulation and test results of the relationship between work climate and fatigue are presented in Table 9.

Table 9. The Relationship between Work Climate and Fatigue at PT. X Sidoarjo in 2018

\begin{tabular}{ccccccc}
\hline \multirow{2}{*}{$\begin{array}{c}\text { Work } \\
\text { Climate }\end{array}$} & \multicolumn{3}{c}{ Occupational Fatigue } & \multicolumn{2}{c}{ Total } \\
\cline { 2 - 5 } & \multicolumn{2}{c}{ Normal } & \multicolumn{2}{c}{ Light } & \multicolumn{2}{c}{} \\
\cline { 2 - 6 } & $\mathbf{n}$ & $\boldsymbol{\%}$ & $\mathbf{n}$ & $\mathbf{\%}$ & $\mathbf{N}$ & $\boldsymbol{\%}$ \\
\hline$\leq \mathrm{TVL}$ & 9 & 100 & 0 & 0 & 9 & 100 \\
$>\mathrm{TVL}$ & 12 & 57.1 & 9 & 42.9 & 21 & 100 \\
\hline
\end{tabular}

From Table 9, it can be seen that from 21 respondents working in the work climate are larger than TVL, there are nine respondents (42.9\%) that experienced light occupational fatigue. Based on the chi-square statistical test, the Fisher's exact value was 0.029 (less than $\alpha=$ 0.05 ), which means that there is a relationship between work climate and occupational fatigue.

\section{The Relationship between Sleep Quality and Fatigue}

Table 10. The Relationship between Sleep Quality and Fatigue at PT. X Sidoarjo in 2018

\begin{tabular}{lcccccr}
\hline \multirow{2}{*}{$\begin{array}{c}\text { Sleep } \\
\text { Quality }\end{array}$} & \multicolumn{2}{c}{ Occupational Fatigue } & \multicolumn{2}{c}{ Total } \\
\cline { 2 - 7 } & Normal & \multicolumn{2}{c}{ Light } & \multicolumn{2}{c}{} \\
\hline Good & 12 & 92.3 & n & \% & N & \% \\
Poor & 9 & 52.9 & 8 & 47.1 & 17 & 100 \\
\hline
\end{tabular}


The cross-tabulation in Table 10 shows that from 17 respondents who had poor sleep quality, eight (47.1\%) among them experienced light occupational fatigue. The result of the chisquare statistical test showed the Fisher's exact value of 0.042 , less than $\alpha(0.05)$, which means that there is a relationship between sleep quality and fatigue.

\section{DISCUSSION}

\section{The Relationship between Age and Fatigue}

Chesnal, Rattu and Lampus (2013) argued that age is directly proportional to the physical work limit that someone can do. Chesnal, Rattu and Lampus (2013) also argued that among men and women, the peak of muscle strength is at the age of 25-35 years old. At the age of 50-60 years, there will be a decrease in muscle strength by 15-25 percent. This indeed will cause someone to experience fatigue. Furthermore, at the age of more than 40 years old, workers experience a decrease in the function of organ physiology, so that the body needs longer time to respond to stimulation, compared to workers below 40 years old (Triyunita, Ekawati and Lestyanto, 2013).

A research conducted by Triyunita, Ekawati and Lestyanto (2013)demonstrated that age has a significant relationship with fatigue. However, this research's result contradicts the previous research: there is no relationship between age and fatigue. The workers who are more than 35 years old do not easily experience fatigue. The research conducted by Chesnal, Rattu and Lampus (2013) also indicated that there is no relationship between age and fatigue. The research conducted by Chesnal, Rattu and Lampus (2013) demonstrated that there is no meaningful relationship between age and occupational fatigue.

\section{The Relationship between Working Period and Fatigue}

Hastuti (2015) argued that working period can positively or negatively affect the level of fatigue. According to Maurits (2010), a person who has a longer working period will have more experiences than another person who has a shorter working period. Someone with a longer working period is indeed more familiar with his/her daily works than someone with a shorter working period. It renders the body to adapt so fatigue will not emerge. Longer work experience also provides its own benefits to the workers, as it accumulates more information regarding the work they do. It will affect work efficiency since the workers have understood the right way of doing their works.

The theory above is also in line with the results obtained with the Spearman correlation test between the working period and fatigue ( $\mathrm{p}$ value $=0.09)$ which indicates that there is no meaningful relationship between both variables. The workers with the working period of more than 10 years do not easily get tired. The results are also supported by the research conducted by Soasa, Josephus and Akili (2013) which demonstrated that there is no relationship between working period and occupational fatigue ( $\mathrm{p}$-value $=0.876)$. Salasa, Kolibu and Punuh (2017) also stated that there is no meaningful relationship between working period and fatigue ( $\mathrm{p}$-value $=0.374$ ). The research conducted by Widyastuti (2017)also suggested that there is no relationship between both variables $(p$-value $=0,823$ )

\section{The Relationship between Physical Workload and Fatigue}

Measurement of physical workload received by the respondents used pulse measurement or palpation method. The use of this method is supported by the statement of Tarwaka (2015) which argued that if there is no Electro Cardio Graph (ECG) during the measurement of physical workload, it can be replaced using a 10-pulse measurement. There are other methods in measuring the physical workload using pulse rate, namely measuring physical workload measurement for 15 or 30 seconds (Tarwaka, Bakri and Sudiajeng, 2004).

According to the research conducted by Wulandari, Widjasena and Ekawati (2016), the result of the statistical test regarding the relationship between workload and fatigue ( $\mathrm{p}$ value $=0.001$ ) indicated that there is a meaningful relationship. It is emphasized with the correlation coefficient value of 0.793 which is close to 1 . Thus, it can be said that the relationship between workload and fatigue has a strong relationship.

According to Lerman et al. (2012), one of roots of fatigue is the workers' workload. The research conducted by National Safety Council (2017) mentioned that $81 \%$ of workers have 
repetitive work. The monotonous, long-term work will also generate fatigue.

The findings indicate that majority of workers have moderate workload level, because several processes of work at the steel casting division at PT. X Sidoarjo use semi-automatic technology. The workers do some of their works manually, such as cutting the billets before being inserted into the billet furnace, deburring, cleaning the slag under the furnace, and repairing things around the descaler. Rahadian (2016) explained that cleaning slag under the billet burner furnace is done by picking up \pm 25 $\mathrm{kg}$ mill scale bucket, shoveling the slag, and it is done repetitively.

Safe Work Australia (2013) stated that excessive work demands will cause fatigue. The monotonous work with high intensity can also accelerate the emergence of fatigue on workers.

\section{The Relationship between Work Climate and Fatigue}

According to the Regulation of the Minister of Manpower and Transmigration (2011), it is stated that the jobs with the working hours of 25\%-30\% have different Threshold Value Limits (TVL) of work climate. The light workload has the Threshold Value Limits (TVL) of $32^{\circ} \mathrm{C}$, the moderate workload has the TVL of $30^{\circ} \mathrm{C}$, and the heavy workload has the TVL of $29^{\circ} \mathrm{C}$.

The findings showed that most respondents $(70 \%)$ worked in the work climate that exceeds the threshold value limits stipulated by the Regulation of the Minister of Manpower and Transmigration (2011). As many as 30\% of workers who work in the work climate that exceeds the TVL experience light fatigue.

According to the statistical test result, there is a relationship between work climate and fatigue. This is in line with the research conducted by Widyastuti (2017) which mentioned that there is a meaningful relationship between both variables. Moreover, Wulandari, Widjasena and Ekawati (2016) research also claimed that there is a relationship between work climate and occupational fatigue.

Grandjean (1979) stated that work environment like noise, work climate, and lighting are the factors causing occupational fatigue. The hot work climate has the impacts on health, namely heat strain, heat stroke, heat exhaustion, heat fatigue, heat collapse, heat cramps, and heat rash (Spellman, 2006).
PT. X Sidoarjo is a steel and wire rod manufacturing company. The process of making steel and wire rod should pass through the steel smelting and casting processes so the raw materials can be formed according to the customer request. This indeed causes the work climate at PT. X Sidoarjo to be above normal. In the steel casting division, there are several works that are performed near the heat source. The heat radiation produced by the heat source causes the workers to be exposed to the radiation during the work. Several works, like deburring, are performed right in front of the billet burner furnace and steel cutting by means of oxidation, and it increases the heat radiation received by the workers. Furthermore, cleaning slag under the furnace also has a hot work climate due to the lack of fresh air circulation.

The finding demonstrated that the fatigue experienced by the workers is still within light category. This enables workers to experience acclimatization toward the work climate in the work area. The acclimatization process will produce a lower pulse rate and the ability of workers to sweat will increase. Furthermore, the behavior of the workers who rest in a cool room also reduces the effects of fatigue caused by the work climate which exceeds the TVL. According to Speegle (2013), drinking water and replacing the lost electrolytes should be done as the impact of heat exposure received by the body. Workers can do another way to replace the lost body fluids by drinking a glass of water every 20 minutes (The National Institute for Occupational Safety and Health and Occupational Safety and Health Administration, 2011).

\section{The Relationship between Sleep Quality and Fatigue}

According to Safe Work Australia (2013), one of the causes of fatigue is poor sleep quality the workers have. The research conducted by the National Safety Council (2017) also stated that there are $43 \%$ of workers who experience fatigue as the impact of poor sleep quality. The commonly occurred sleep disorders are sleep apnea and insomnia.

Grandjean (1979) argued that fatigue can be caused by several factors, such as environmental conditions, inappropriate circadian rhythm, nutritional intake, diseases and pain, physical and mental intensity and work duration, and several other causes. The 
argument is supported by (Wickens et al., 2004) which claimed sleep disturbance is caused by several factors, namely disruption of a person's circadian rhythm due to jet lag and shift work.

Safe Work Australia (2013) explained that adults generally have different sleep duration. Under normal condition, adult's sleep duration is 7-8 hours. Adults with sleep duration of less than 7-8 hours will experience the accumulation of it until they have sufficient sleep duration. The circadian rhythm functions as the regulator of sleep pattern, heart rate, body temperature, hormones, and digestive system. The circadian rhythm can also influence someone's alertness, behavior, reaction speed, and mental capacity.

The results of this research indicated that there is a relationship between sleep quality and fatigue. These results are also supported by the research conducted by Trisnawaty (2012)that demonstrated $p$-value of $0.000(\alpha=0.05)$, which means that there is a significant relationship between both variables.

Respondents are the steel casting workers at PT. X Sidoarjo who work at the morning shift. Based on the measurement of sleep quality, most of the respondents had poor sleep quality although they did not work at night shift schedule. It is caused by a lack of sleep duration. Respondent's poor sleep quality is because they delay their activities until late at night. Therefore, there were several respondents who woke up at night to go to the restroom. This is contrary to the circadian rhythm, because at night, the circadian rhythm regulates the functions of several body organs to rest.

\section{CONCLUSION}

There were workers who experienced fatigue at the steel casting division at PT. X Sidoarjo. The measurement result of the highest work climate was at point $\mathrm{B}$ of the Billet Reheating Furnace (BRF) and the lowest work climate was at point B of Descaler. Majority of the workload received by the workers was at the moderate level. The questionnaire results of the Pittsburgh Sleep Quality Index (PSQI) stated that the sleep quality of the workers was poor. The correlation test results indicated that there was no relationship between individual factors and fatigue. There was a moderate relationship between work climate, workload, and fatigue; while the relationship between physical workload and fatigue was weak.

\section{ACKNOWLEDGMENT}

The researchers would like to express utmost gratitude toward Mrs. Indriati Paskarini, S. H., M. Kes. as the research advisor.

\section{REFERENCES}

Chesnal, H., Rattu, A. J. . and Lampus, B. . (2013) 'The Relationship Between Age, Gender, and Nutritional Status with Work Fatigue in Workers in the Production Section of PT. Karangetang Popontolen of South Minahasa', Jurnal Kesehatan Masyarakat Universitas Sam Ratulangi Manado, 1(1), pp. 1-7.

Grandjean, E. (1979) 'Fatigue in industry', British Journal of Industrial Medicine, 36, pp. 175-186.

Hastuti, D. D. (2015) Relations between the Length of Work and the Fatigue of Construction Worker of PT. Nusa Raya Cipta Semarang. Undergraduate Thesis. Semarang: Faculty of Sports and Health Science Universitas Negeri Semarang.

Lerman, S. E. et al. (2012) 'Fatigue Risk Management in the Workplace', Journal of Occupational and Environmental Medicine, 54(2), pp. 259-260.

Maurits, L. S. K. (2010) A Glance About Exhaustion of Work. Yogyakarta: Amara Books.

Minister of Manpower and Transmigration of the Republic of Indonesia (2011) Regulation Number PER.13/MEN/X/2011 on Threshold Value of Physical and Chemical Factors in Workplaces. Jakarta: Minister of Manpower and Transmigration.

National Safety Council (2017) Fatigue in the Workplace: Causes \& Consequences of Employee Fatigue. Itasca: National Safety Council.

President of the Republic of Indonesia (1970) Law Number 1 of 1970 about Occupational Safety. Jakarta: President of the Republic of Indonesia.

Rahadian, R. R. (2016) The Relationship between Heat Pressure and Workload with Increasing the Pulse Rate of Workers in the BRF and TFH Work Areas at PT. X. Undergraduate Thesis. Surabaya: Faculty of Public Health Universitas Airalngga.

Safe Work Australia (2013) Guide For Managing The Risk Of Fatigue At Work. 
Australia: Safe Work Australia.

Salasa, N., Kolibu, F. and Punuh, M. (2017) 'The Relationship between Age, Period of Employment, and Nutritional Status with Work Fatigue in the Loining Section PT. Sinar Pure Food International', Media Kesehatan, 9(3), pp. 1-9.

Soasa, M., Josephus, J. and Akili, R. H. (2013) 'The Relationship of the Individual with the Fatigue Factor Manpower Loading and Unloading at the Port of Manado', Jurnal Kesehatan Masyarakat Sam Ratulangi, 1(1), pp. 1-7.

Speegle, M. (2013) Safety, Health, and Environmental Concepts for the Process Industry. New York: Delmar.

Spellman, F. R. (2006) Industrial Hygiene Simplified. United States of America: Government Institutes.

Suma'mur, P. (2009) Corporate Hygiene and Occupational Health. Jakarta: CV Sagung Seto.

Tarwaka (2015) Industrial Ergonomics: Basics of Ergonomics Knowledge and Applications at Work. 2nd edn. Surakarta: Harapan Press.

Tarwaka, Bakri, S. H. A. and Sudiajeng, L. (2004) Ergonomics for Safety, Occupational Health and Productivity. 1 st edn. Surakarta: UNIBA Press.

The National Institute for Occupational Safety and Health and Occupational Safety and Health Administration (2011) Protecting Workers from Heat Stress. Washington, D.C: The National Institute for
Occupational Safety and Health,

Occupational Safety and Health

Administration

Trisnawaty, E. (2012) 'Sleep Quality, Nutritional Status and Fatigue in Women with Dual Role Workers', in Prosiding Seminar Nasional Kesehatan Jurusan Kesehatan Masyarakat FKIK UNSOED, pp. 1-16.

Triyunita, N., Ekawati and Lestyanto, D. (2013) 'The Relations of the Physical Workload, Noise and Individual Factors with Worker Fatigue on Weaving part PT. X Batang', Jurnal Kesehatan Masyarakat FKM Undip, 2(2), pp. 1-11.

Wickens, C. D. et al. (2004) An Introduction to Human Factors Engineering. 2nd edn. New Jersey: Prentice Hall.

Widyastuti, A. D. (2017) Relationship between Individual Characteristics, Work Climate, Workload, Job Stress with Job Fatigue (Study on Workshop Area Workers at PT. Star Queen Indonesia). Undergraduate Thesis. Surabaya: Faculty of Public Health Univeristas Airlangga.

Wulandari, K., Widjasena, B. and Ekawati, E. (2016) 'The Relationship between Manual Physical Workload and Work Climate with Fatigue in the Construction Worker in Project of Mechanical Workshop Renovation', Jurnal Kesehatan Masyarakat (e-Journal) FKM Undip, 4(3), pp. 425-435. 